\title{
Strategi Meminta Secara Verbal Anak Usia Dini Usia 6 Tahun
}

\author{
Muhammad Usman ${ }^{1,2} \bowtie$, Nidar Yusuf ${ }^{3}$, Wahyu Khafidah ${ }^{1}$ \\ Pendidikan Islam Anak Usia Dini, Universitas Serambi Mekkah, Indonesia(1); Pendidikan \\ Bahasa Inggris, Universitas Serambi Mekkah, Indonesia(2); Pendidikan Guru Sekolah Dasar, \\ Universitas Muhammadiyah Jakarta, Indoenesia( ${ }^{(3)}$ \\ DOI: $\underline{10.31004 / \text { obsesi.v6i4.2245 }}$
}

\begin{abstract}
Abstrak
Anak usia dini dalam mengajukan permintaan bisa verbal maupun non verbal, Kenyataannya orang dewasa kurang memahami, orang dewasa memenuhi permintaan anak tetapi tidak mendukung. Permintaan anak tidak hanya mencapai tujuan pribadi melainkan juga tujuan sosial. Penelitian ini bertujuan memperoleh informasi dan mendalami strategi meminta dalam bentuk verbal. Penelitian ini menggunakan metode deskriptif. Pengumpulan data digunakan teknik rekam dan catat. Rekaman dilakukan dari anak bangun tidur pagi hari sampai malam. Instrumen penelitian berupa kartu data yang memuat tuturan anak usia 6 tahun. Berdasarkan hasil analisis strategi anak yaitu; 1. anak usia 6 tahun mengajukan permintaan, bila yang diminta merupakan kebiasaan dilakukan berulang. Permintaan menggunakan kata imperative seperti, minta, belikan, ambilkan, 2. anak mengajukan permintaan langsung ada dua cara; langsung ke target dan permintaan dengan alasan/ argumentasi. Sesuatu yang diminta merupakan hak yang sudah seharusnya 3. anak melakukan permintaan bila ada dunkungan moral, anak lebih berani dengan alasan dan argumentasi.
\end{abstract}

Kata Kunci: strategi meminta; anak usia dini; usia 6 tahun

\begin{abstract}
Early childhood in making requests can be verbal or non-verbal. In fact, adults do not understand the purpose of children's requests, many adults fulfill children's requests but do not support them positively. Children's requests not only achieve personal goals but also social goals as well as the strategies used. This study aims to obtain information and explore strategies for asking in verbal form. This research method is descriptive method. The data collection technique is a recording and note-taking technique. The recording is done from the time the child wakes up in the morning until the evening. The instrument of this research is a data card containing the speech of children aged 6 years. Based on the results of the strategy analysis, the child propose a request under several conditions, namely; 1 . if what is requested is a habit that occurs repeatedly. 2. the child in submitting his request if something requested is a right that should be. 3 , the child makes a request if there is moral support.
\end{abstract}

Keywords: asking strategy; early childhood education; 6 years old

Copyright (c) 2022 Muhammad Usman, et al.

$\triangle$ Corresponding author:

Email Address : muhammad.usman@serambimekkah.ac.id (Banda Aceh, Indonesia)

Received 5 November 2021, Accepted 2 February 2022, Published 24 February 2022 


\section{PENDAHULUAN}

Komunikasi verbal merupakan cara komunikasi yang paling jelas dipahami, dan tentu saja merupakan alat yang ampuh dalam komunikasi. Sederhananya, komunikasi verbal adalah berbagi informasi antara dua individu dengan menggunakan kata. Sementara nonverbal yaitu transfer informasi melalui penggunaan bahasa termasuk kontak mata, ekspresi wajah, gerak tubuh dan banyak lagi. Misalnya, tersenyum saat seseorang bertemu dengan seseorang. Setiap orang menggunakan komunikasi nonverbal sepanjang waktu apakah mereka mengetahuinya atau tidak (Wahyuni, 2018). Dalam hal ini, anak usia dini dalam mengajukan permintaan bisa verbal maupun non verbal (Lee et al., 2021), kenyataannya orang dewasa kurang memahami tujuan permintaan anak secara verbal sehingga banyak orang dewasa memenuhi permintaan anak tetapi perlakuan tersebut tidak mendukung secara positif (Wolf, 1978)(Yoder \& Warren, 2002). Dalam mengajukan permintaannya, anak tidak hanya mencapai tujuan pribadi melainkan juga tujuan sosial sebagaimana strategi yang digunakan oleh anak (Hovy \& Yang, 2021). Sementara itu, masa usia dini terutama usia SD kelas awal (6-8 tahun) merupakan usia paling menentukan bagi perkembangan pada masa-masa berikutnya (Gratzer, 2008). Berdasarkan tahap-tahap proses perkembangan, usia dini ini berada dalam tahap berpikir operasional konkret (6-11 tahun) Jean Peaget yang di kutip oleh Muhammad Usman (Usman, 2015). Masa ini Ramda et al. (2018) ditandai dengan kemampuan anak untuk melakukan tugas-tugas konservasi yang meliputi kemampuan memahami proses yang terjadi dalam suatu kegiatan, memahami hubungan antar peristiwa, memahami hubungan timbal balik (resiprokasi) dan memahami identitas segala sesuatu yang berada disekitarnya. Sementara Jannah (2015) menyebut masa ini sebagai periode paling menyulitkan, periode kritis dan periode kreatif. Hal ini disebabkan oleh perilaku anak yang lebih banyak dipengaruhi oleh teman-teman sebayanya dari pada oleh orang tuanya atau anggota keluarga lain. Pada masa ini anak diharapkan memperoleh dasar-dasar pengetahuan dan keterampilan yang dianggap penting bagi kehidupannya di masa yang akan datang (Loukatari et al., 2019). Oleh karena itu dibutuhkan pemahaman dan kebijaksanaan tersendiri terhadap kehidupan anak pada usia dini, agar perkembangan anak dapat berjalan sesuai dengan yang diharapkan.

Periode masa anak usia dini, antara lain periode sintese-fantastis. Periode ini, pengamatan anak adalah kesan umum yang masih samar-samar dan dilengkapi dengan imaginasi/fantasi anak (Christiana, 2018). Oleh sebab itu, pada periode ini anak senang dengan kegiatan mendongeng, cerita tentang membangkitkan daya khayal. Sementara itu, khusus berkaitan dengan kemampuan bertutur, Jannah (2015) menyatakan bahwa pada masa ini anak mulai menyadari bahwa bertutur merupakan sarana penting untuk memperoleh tempat di dalam kelompok. Anak juga menyadari bahwa bentuk-bentuk komunikasi sederhana seperti menangis dan gerak isyarat secara sosial tidak sepenuhnya diterima lagi. Hal ini mendorong anak untuk memperbaiki kemampuan bertuturnya sehingga dapat bertutur lebih baik. Lebih lanjut, tindak tutur dari orang tua dalam lingkungan keluarga mempengaruhi pada perkembangan Bahasa anak (Findy Novita, 2020).

Ketika anak mengalami perkembangan biologis serta kognitif maka keterampilan bahasa anak usia 6 tahun biasanya akan mengalami perkembangan juga (Anggraini, 2021). Saat anak ingin memahami bahasa, biasanya anak menunjukan khas tersendiri yang mana akan terlihat perbedaan dengan orang dewasa. Dalam kaitan ini Fauziah \& Rahman (2021) menyatakan bahwa dalam berbahasa, anak menciptakan struktur, pola atau kaidah bahasa khas milik anak. Lebih dari itu anak sering menggunakan strategi yang khas dalam menerima pajanan bahasa, menginternalisasikannya, dan kemudian menggunakannya dalam berkomunikasi terutama dalam mengajukan permintaannya (Lee et al., 2021).

Penggunaan bentuk verbal yang bermacam-macam dalam mengajukan permintaan ini sejalan dengan pandangan bahwa bentuk tuturan yang bermacam-macam dapat digunakan untuk menyampaikan maksud yang sama, sebaliknya berbagai macam maksud dapat disampaikan dengan tuturan yang sama (Sastra et al., 2016). Sementara itu, beberapa pakar 
lain juga mengemukakan bahwa dalam tindak tutur, penutur tidak selalu hanya bermaksud untuk mencapai tujuan-tujuan pribadi, yakni untuk memperoleh sesuatu, tetapi juga berusaha menjaga hubungan baik dengan mitra tuturnya dan mengusahakan agar interaksi berjalan dengan baik dan lancar. Dengan kata lain, dalam mengajukan permintaannya, anak usia dini tidak hanya berusaha mencapai tujuan pribadi melainkan juga untuk mencapai tujuan sosial. Kenyataan adanya tujuan sosial disamping tujuan pribadi tersebut mendorong anak menggunakan bentuk-bentuk verbal yang bermacam-macam (Hovy \& Yang, 2021).

Fenomena di atas sangat menarik untuk dicermati lebih jauh demi memperoleh informasi lebih mendalam tentang bentuk-bentuk verbal yang digunakan oleh anak-anak dalam mengajukan permintaan. Oleh karena itu secara umum penelitian ini bermaksud untuk memperoleh informasi dan mendalami strategi meminta dalam berbahasa Indonesia oleh anak usia dini (usia 6 tahun). Agar diperoleh informasi secara mendalam tentang strategi yang digunakan oleh anak dalam mengajukan permintaannya, kajian dalam penelitian ini terutama difokuskan pada bentuk verbal yang digunakan dalam mengajukan permintaan secara langsung (permintaan langsung pada sasaran dan permintaan langsung dengan argumentasi). Permintaan langsung adalah permintaan yang menggunakan bentuk direktif penanda permintaan.

Secara umum penelitian ini bermaksud untuk mengetahui bagaimanakah strategi meminta anak usia 6? Pada studi ini peneliti ingin memperoleh informasi dan mendalami strategi meminta dalam berbahasa Indonesia oleh anak, terutama difokuskan pada bentuk verbal yang digunakan dalam mengajukan permintaan secara langsung (permintaan langsung pada sasaran dan permintaan langsung dengan argumentasi).

Berdasarkan hasil temuan bahwa studi ini difokuskan pada bentuk verbal yang digunakan dalam mengajukan permintaan secara langsung, anak mengajukan permintaan dalam beberapa kondisi yaitu permintaan langsung pada sasaran dan permintaan langsung dengan alasan atau argumentasi. Pada penelitiaan ini secara spesifik menyelesaikan permasalahan bagaimana anak mengajukan permintaan langsung pada sasaran, bagaimana anak mengajukan permintaan langsung dengan alasan/argumentasi, dan bagaimana anak mengajukan permintaan jika terdapat dukungan moral dari seseorang yang menurut anak dapat diandalkan.

Ada beberapa studi yang relevan pernah dilakukan antara lain strategi meminta maaf. Studi ini ingin mengetahui bagaimana penggunaan tindak tutur ekspresif permintaan maaf anak usia 5 tahun (Setyowati, 2020). The use of questions as problem-solving strategies during early childhood, studi ini meneliti penggunaan strategi pertanyaan untuk memecahkan masalah di awal (Legare et al., 2013).

\section{METODOLOGI}

Metode yang digunakan dalam penelitian ini meliputi metode deskriptif yang bertujuan untuk menggambarkan strategi anak usia dini dalam melakukan permintaan secara verbal. Studi ini sesuai dengan yang dikatakan pada studi deskriptif kualitatif yang merupakan pendekatan dalam diri sendiri (Pranita et al., 2018). Dalam studi ini di jelaskan tentang yang menggambarkan hasil dari pengumpulan data apa adanya. Sumber data dilapangan tentang strategi meminta dalam berbahasa Indonesia memiliki responden anak usia 6 tahun bernama Aira. Dalam penelitian ini peneliti sendiri sebagai Instrumen. Dalam proses penelitian, peneliti menggunakan pedoman observasi dalam pengamatan di lapangan agar mendapatkan data data pendukung yang relevan dengan permasalahan penelitian (Raco, 2018).

Pengumpulan data pada studi ini dilakukan dengan menggunakan teknik rekam dan catat, Musyikawati (2015) menyampaikan deskriptif kualitatif dapat menggunakan Teknik pengumpulan data yaitu wawancara, simak dan rekam. Dengan demikian diperlukan 
rekaman setiap tuturan dari subyek serta mencata semua kejadian yang dianggap penting saat pengambilan data berlangsung. Rekaman kegiatan dan tuturan subyek dilakkan dari saat anak bangun tidur di pagi hari sampai anak tidur di malam hari. Peneliti merupakan instrument pada studi ini. Dalam mengunpulkan data alat yang digunakan terdiri dari kartu data yang memuat tuturan anak usia 6 tahun. Tahapan penelitiand dapat disajikan pada bagan pada gambar 1.

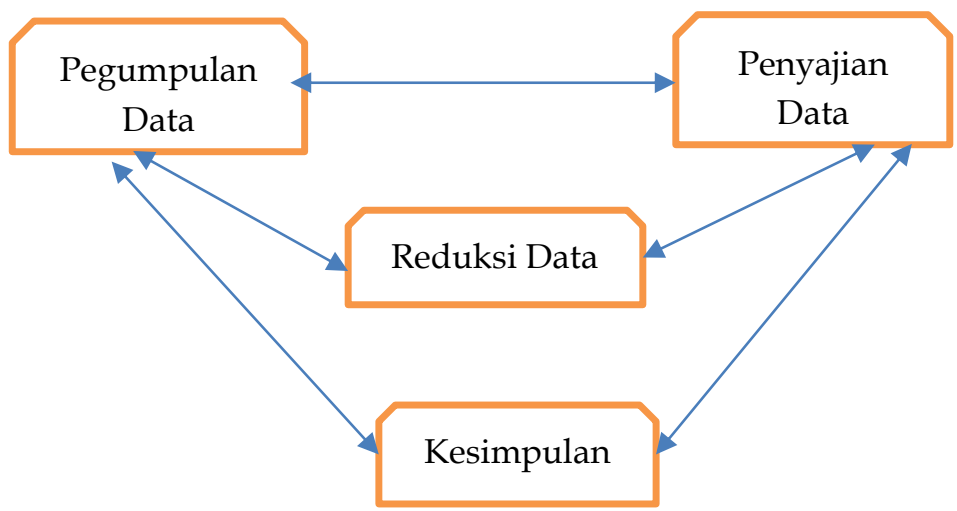

Gambar 1. Bagan Tahapan Design Penelitian

\section{HASIL DAN PEMBAHASAN}

Bentuk verbal yang dimaksudkan dalam penelitian ini adalah bentuk bahasa yang digunakan oleh anak usia dini (usia 6 tahun) dalam mengajukan permintaannya, selain bahasa isyarat yang menggunakan gerak anggota tubuh dan mimik wajah. Penggunaan bentuk verbal yang bermacam-macam ini juga sejalan dengan pandangan bahwa dalam sebuah peristiwa komunikasi, penutur tidak selalu hanya bermaksud untuk memperoleh sesuatu dari mitra tutur, melainkan juga berusaha menjaga hubungan baik dengan mitra tuturnya dan mengusahakan agar interaksi berjalan dengan baik dan lancar.

Permintaan langsung yang dimaksudkan dalam penelitian ini adalah permintaan yang diajukan dengan menggunakan kata-kata imperative penanda permintaan, seperti minta, belikan, ambilkan, keluarkan dan sebagainya. Hasil analisa data menunjukkan bahwa permintaan secara langsung yang dilakukan oleh anak usia dini (usia 6 tahun) dapat diklasifikasikan kedalam dua klasifikasi, yaitu permintaan langsung pada sasaran dan permintaan langsung dengan alasan atau argumentasi.

\section{Permintaan langsung pada sasaran}

Dalam mengajukan permintaannya, anak usia dini (usia 6 tahun) sering melakukannya dengan cara menyebut langsung 'sesuatu' yang diminta tanpa basa basi. Artinya permintaan langsung tersebut tidak disertai dengan tambahan pernyataan apapun, baik pernyataan-pernyataan untuk mengkondisikan permintaan sebelum permintaan diajukan maupun alasan-alasan atau argumentasi untuk mendukung pengajuan permintaan sesudah permintaan tersebut diajukan. Hal ini disebabkan oleh adanya kenyataan bahwa kondisi-kondisi yang melatarbelakangi permintaan anak memungkinkan bagi anak untuk merasa tetap dapat mempertahankan keberlangsungan dan kesantunan komunikasi meskipun diajukan dengan menggunakan bentuk permintaan langsung pada sasaran.

Berdasarkan hasil analisi data, ditemukan bahwa permintaan langsung pada sasaran digunakan oleh anak untuk mengajukan permintaan dalam beberapa kondisi sebagai berikut: pertama, permintaan langsung pada sasaran digunakan oleh anak usia dini (usia 6 tahun) jika 'sesuatu' yang diminta merupakan kebiasaan yang selalu terjadi secara berulang-ulang. Permintaan 'minum susu' pada wacana (1) dan permintaan tentang 'uang saku' pada wacana (2) merupakan contoh tentang hal tersebut. Gambaran permintaan langsung disajikan pada gambar 2 . 


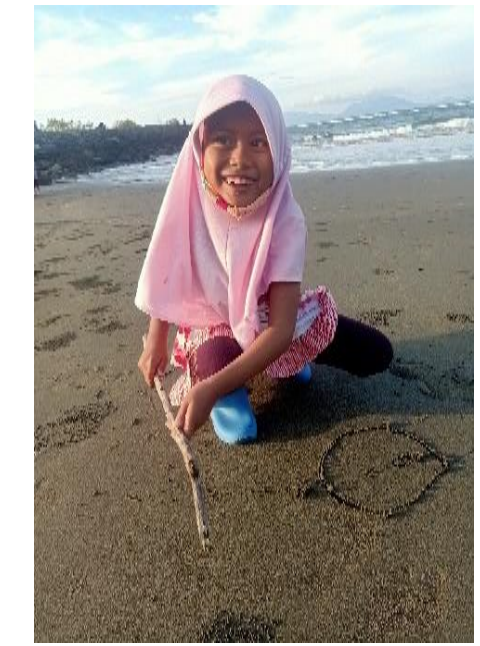

Aira Minta uang buat beli mainan ya

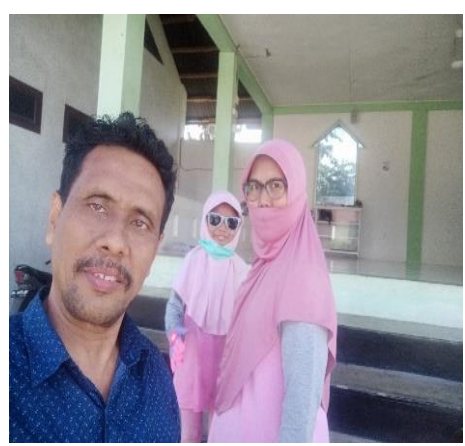

Aira: Pak.. ke Dunkin pak (memegang tangan bapak)

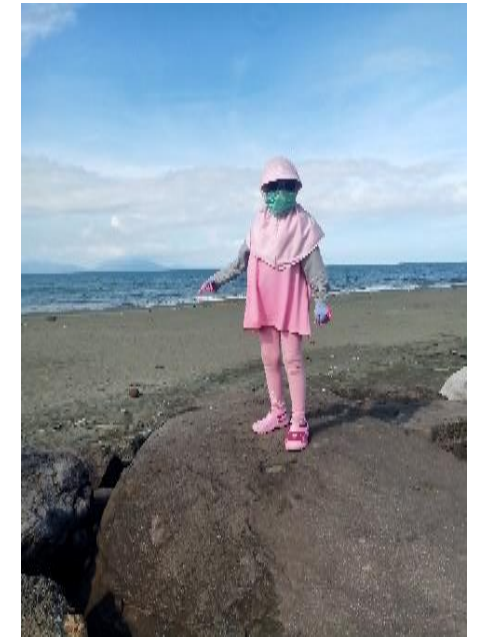

Aira Minta Topi

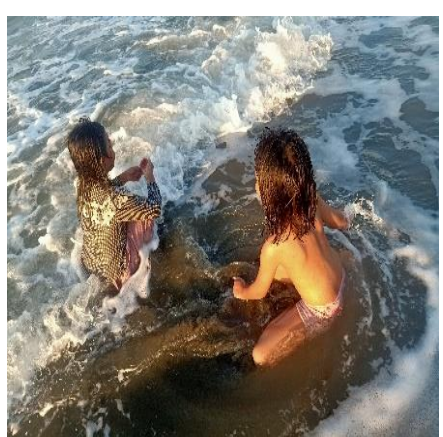

Ibu: Masuk sekolah masih lama, saat mandi di laut

\section{Gambar 2 Permintaan Langsung}

(1) Aira: buk, buatin susu buk (sambil berbalik menghadap ke arah tembok setelah selimutnya ditarik oleh ibunya

Ibu : Ya sebentar, tunggu ya

(2) Aira: Buk, minta uang sakunya buk (sambil membetulkan tali sepatunya yang belum tertalikan secara baik)

Ibu : Ambil di buffet ya.

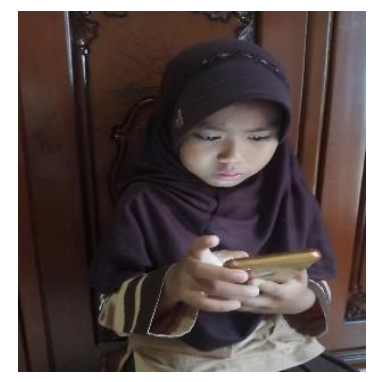

Gambar 3 Aira meminta uang saku
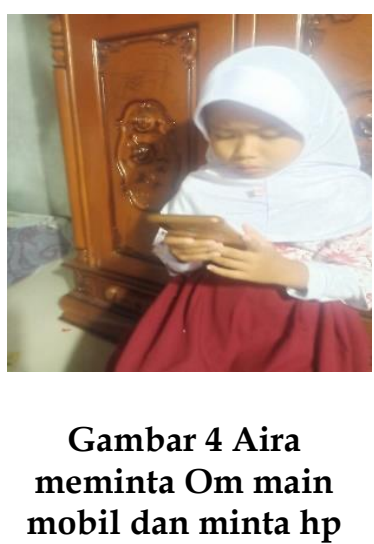
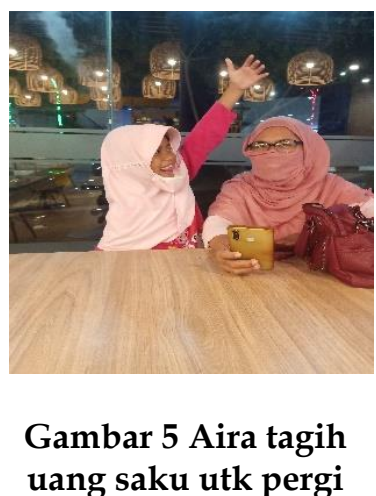

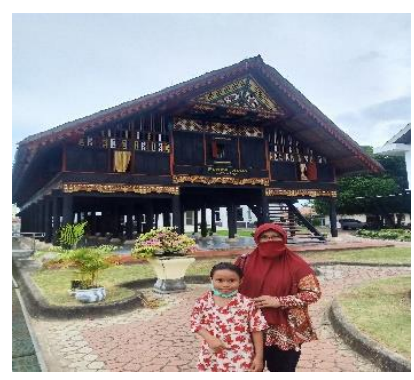

Gambar 6 Aira meminta coklat dan pergi bersama

Peristiwa tutur pada contoh data wacana (1) terjadi pada saat anak akan bangun tidur di pagi hari dan ibu sedang melipat selimut yang digunakan oleh anak dalam tidur malamnya. Sebelum turun dari tempat tidur Ruby meminta kepada ibunya untuk dibuatkan minuman 
susu kesukaannya. Permintaan seperti ini merupakan kebiasaan yang selalu terjadi secara berulang-ulang setiap kali Aira akan bangun tidur di pagi hari. Demikian pula halnya dengan peristiwa tutur pada data wacana (2), peristiwa tutur seperti contoh data pada wacana (2) ini selalu terjadi setiap kali Aira akan berangkat ke sekolah di pagi hari. Dengan kebiasaan yang selalu terjadi secara berulang dan tidak pernah mendapatkan penolakan terhadap permintaan tersebut, anak merasa bahwa "sesuatu" yang diminta tersebut sudah pasti didapatkan. Pengajuan permintaan hanya berfungsi sebagai sarana pemberitahuan kepada mitra tutur bahwa 'saat' untuk 'minum susu' dan 'pemberian uang saku' sudah tiba waktunya. Kenyataan tersebut tampaknya membuat anak tidak lagi merasa punya beban psikologis untuk mengajukan permintaannya. Anak merasa yakin bahwa permintaan yang diajukannya tidak akan mengganggu hubungan baik dan kelancaran komunikasi anak dengan mitra tuturnya. Yang penting bagi anak adalah bagaimana dapat menyampaikan permintaannya secara singkat dan jelas kepada mitra tutur.

Hal serupa juga terjadi ketika anak menerima baju ganti sesudah mandi, minta dipeluk (dikelon) ketika tidur, dan minta minum ketika disuap (makan). Kedua, permintaan langsung pada sasaran digunakan oleh anak usia dini dalam mengajukan permintaannya jika sesuatu yang diminta oleh anak merupakan 'hak' yang sudah seharusnya diterima oleh anak dari mitra tuturnya. Hal ini bisa berarti bahwa 'sesuatu' yang diminta oleh anak dari mitra tutur tersebut merupakan milik pribadi anak yang sedang dipinjam, dipakai, atau dititipkan kepada mitra tutur seperti tampak pada contoh wacana berikut:

(3) Aira: Om, mana om mobil remotku (mendatangi omnya yang sedang memainkan mobilmobilan anak).

Om Iwan: Entar to dik. nyobak, susah mana nyetir beneran sama nyetir remot control.

Aira: Nanti rusak lho, ditabrak-tabrakkin gitu

Om: Ha...ha...ha......susah juga ternyata (menyerahkan pada Aira)

(4) Aira: Pak, uang yang bapak janjiin mana pak (mencegat bapak didepan pintu).

Bapak: Sabar, ambilkan minum bapak dulu.

Aira: tapi besok lho mau tak pakai

Bapak: Ayuk! Mbok ya nanti, bapak khan masih capek.

Peristiwa tutur pada contoh data wacana (3) terjadi pada suatu sore di teras rumah. Pada saat itu mobil-mobilan anak sedang dipinjam dan dimainkan oleh om Iwan. Oleh karena itu, ketika anak ingin meminta mobil tersebut untuk dimainkan sendiri, tanpa ragu-ragu anak meminta dengan menggunakan permintaan langsung pada sasaran. Hal tersebut terjadi karena anak merasa bahwa tidak ada alasan bagi mitra tutur untuk tidak mengabulkan permintaannya karena mobil-mobilan tersebut memang milik anak sendiri. Demikian juga halnya dengan contoh data pada wacana (4). Peristiwa tutur tersebut terjadi pada siang hari saat bapak baru pulang dari kampus, sudah cukup lama uang yang dijanjikan oleh bapaknya dan belum juga diberikan kepada anak. Ketika anak memerlukan uang tersebut tanpa raguragu memintanya kepada bapak dengan menggunakan bentuk permintaan langsung pada sasaran, sama halnya contoh data pada wacana (3). Hal ini terjadi karena anak merasa bahwa uang yang diminta dari bapaknya tersebut adalah uang miliknya sendiri yang sudah seharusnya diberikan oleh bapak kepada anak. Latar belakang seperti itu menyebabkan anak tidak merasa perlu memperhitungkan hal-hal lain selain efektifitas penyampaian informasi kepada mitra tuturnya.

Ketika, permintaan langsung pada sasaran digunakan oleh anak usia dini (usia 6 tahun) jika kedekatan hubungan antara anak dengan mitra tutur yang dihadapi termasuk dalam kategori sangat dekat dan status sosial dari segi usia anak lebih tua atau sederajat dengan mitra tuturnya. Dengan kedekatan hubungan dan kesederajatan usia tersebut, anak merasa tidak punya beban psikologis untuk mengajukan permintaan secara langsung pada sasaran, terutama jika' sesuatu' yang dimintanya bukan merupakan permintaan kategori 'luar biasa'. Data seperti pada wacana (5) dan (6) merupakan contoh tentang hal tersebut. 
DOI: 10.31004/obsesi.v6i4.2245

(5) Aira: Nda, aku minta topnya satu (mengambil top 'sejenis coklat' dari lemari kue).

Nanda: Besok mau tak bawa sekolah lho kak.

Ruby: Satu aja Nda.

Nanda: Kakak ini, aku Cuma bawa satu deh.

(6) Aira: Kak, minta kak (mendekati Nazwa yang sedang makan coklat)

Nazwa: Punyamu mana?

Aira: Dikit aja kak.

Nazwa: kamu ini (memberikan sepotong)

Peristiwa tutur pada contoh data pada wacana (5) terjadi pada sore hari diruang makan keluarga. Kedekatan hubungan antara Nanda dan Aira pada contoh data wacana (5) termasuk dalam kategori sangat dekat sebab mereka kakak beradik. Sementara itu, dari segi usia dan kedudukan atau peran individu dalam keluarga, mereka berada pada posisi sederajat atau lebih kurang sama. Dalam kondisi semacam itu, tidak diperlukan basa basi bagi anak untuk menjaga hubungan baik dan kesopansantunan antara anak dan mitra tuturnya ketika harus mengajukan permintaan. Anak tidak merasa melanggar prinsip sopan santun meskipun menggunakan bentuk permintaan langsung pada sasaran, sedangkan mitra tuturnya juga merasa tidak dilanggar hak dan harga dirinya oleh penggunaan bentuk verbal permintaan tersebut. Hal ini sejalan dengan pandangan bahwa tingkat kedekatan hubungan atau keakraban antara penutur dan mitra tutur berbanding terbalik dengan tingkat kesantunan yang diperlukan dalam berkomunikasi. Artinya, semakin dekat dan akrab hubungan antara penutur dan mitra tutur, semakin tidak diperlukan sikap-sikap santun dalam berkomunikasi, sebaliknya semakin jauh jarak keakraban antara penutur dan mitra tutur, semakin diperlukan adanya sikap dan perilaku yang santun dalam berkomunikasi. Demikian pula halnya dengan contoh data pada wacana (6), kedekatan hubungan antara Aira dan Nazwa juga termasuk dalam klasifikasi sangat dekat dan status sosial mereka baik dari segi peran dalam keluarga atau lingkungan dan dari segi usia berada pada tataran yang lebih kurang sama. Oleh karena itu untuk mengajukan permintaannya, anak menyampaikannya dengan menggunakan permintaan langsung pada sasaran.

Keempat, permintaan langsung pada sasaran digunakan oleh anak usia dini (usia 6 tahun) untuk mengajukan permintaan jika terdapat dukungan moral dari seseorang yang menurut anak dapat diandalkan, yakni seseorang yang memilki kedudukan atau kekuasaan yang besar dan memiliki pengaruh terhadap mitra tutur yang dihadapi oleh anak. Wujud dukungan tersebut dapat berupa persetujuan akan 'sesuatu' yang diminta oleh anak maupun janji yang pernah disampaikan kepada anak oleh seseorang yang dapat diandalkan anak tersebut. "ibu" pada contoh data pada wacana (7) dianggap oleh anak sebagai seseorang yang layak diandalkan untuk memberikan dukungan moral dalam meminta dunkin donat kepada bapak dengan menggunakan bentuk permintaan langsung pada sasaran.

Sebaliknya, 'bapak' pada contoh data wacana (8) dianggap sebagai seseorang yang layak diandalkan pengaruhnya oleh anak untuk memberikan dukungan moral dalam meminta buku kepada ibu dengan menggunakan bentuk permintaan langsung pada sasaran.

(7) Aira: pak. Ke dunkin pak (memegang tangan bapak, keluar dari sebuah rumah sakit).

Bapak: Malam minggu aja ya, rame-rame.

Ruby: Bapak rek, kata ibu habis cabut gigi beli dunkin donat.

Bapak: ya wis, ya wis....

(8) Aira: buk beli buku buk. (sambil memegang tangan ibu disebuah toko buku).

Ibu: masuk sekolah khan masih lama

Aira: kata bapak lho beli sekarang, jadi bisa belajar dari sekarang.

Ibu: sudah bilang bapak tho....?

Peristiwa tutur pada contoh data wacana (7) terjadi disebuah rumah sakit. Dengan diantar oleh bapaknya, anak mencabutkan giginya yang sudah goyah, kepada dokter gigi di rumah sakit tersebut. Sebelumnya, untuk merayu anak agar mau mencabutkan giginya yang 
sudah goyah, anak boleh membeli dunkin donat kesukaannya. Perkataan tersebut oleh anak dianggap sebagai dukungan moral terhadap pengajuan permintaannya kepada bapak untuk membeli dunkin donat. Dengan dukungan moral tersebut anak tidak merasa sangsi untuk mengajukan permintaan tersebut kepada bapak. Mskipun yang diminta oleh anak merupakan permintaan yang 'tidak biasa' karena Selma ini ' membeli dunkin donat' hanya dilakukan pada saat-saat yang agak istimewa. Sementara itu, contoh wacana (8) terjadi disebuah toko buku. Pada waktu akan berangkat ke toko tersebut bapak mengatakan kepada anak bahwa anak boleh membeli buku agar segera dapat belajar jauh-jauh hari sebelum masuk sekolah setelah libur panjang. Perkataan bapak tersebut oleh anak dianggap sebagai dukungan moral untuk minta dibelikan buku pelajaran kepada ibunya. Dengan jaminan tersebut, anak memiliki rasa percaya diri untuk mengajukan permintaannya dengan menggunakan bentuk permintaan langsung pada sasaran. Anak merasa tidak perlu menggunakan bentuk permintaan secara tidak langsung untuk menjaga hubungan baik dengan mitra tutur yang dihadapinya karena telah mendapatkan dukungan moral dari seseorang yang dapat diandalkannya. Seperti halnya dengan kasus pertama, kedua dan ketiga, target anak dalam kondisi ini adalah dapat menyampaikan permintaan seefektif dan seinformatif mungkin tanpa harus mempertimbangkan faktor-faktor kesantunan komunikasi.

Dengan demikian, berdasarkan hasil analisis data ditemukan bahwa bentuk permintan langsung pada sasaran digunakan oleh anak jika dilatarbelakangi oleh kondisikondisi sebagai berikut: (1) 'sesuatu' yang dinta oleh anak merupakan kebiasaan yang sering terjadi scara berulang-ulang, (2) 'sesuatu' yang diminta oleh anak merupakan hak yang sudah seharusnya diterima oleh anak dari mitra tuturnya, (3) mitra tutur yang dihadapi oleh anak memiliki kedekatan hubungan yang sangat erat dan status social dari segi usia dan kedudukan atau peran individu dalam keluarga lebih kurang sama dengan anak, dan (4) terdapat dukungan moral (backing) berupa persetujuan, janji atau anjuran tentang permintaan anak dari seseorang yang menurut anak, berpengaruh terhadap mitra tutur yang dihadapi oleh anak. Gambar 3,4,5 dan 6 disajikan ilustrasi permintaan langsung anak.

\section{Permintaan langsung dengan alasan/argumentasi}

Permintaan langsung dengan alasan atau argumentasi yang dimaksudkan dalam penelitian ini adalah permintaan yang diajukan secara langsung oleh anak kepada mitra tuturnya yang disertai dengan pernyataan-pernyataan yang digunakan oleh anak untuk meyakinkan atau mempengaruhi mitra tutur agar memahami dan memaklumi permintaannya dan pada akhirnya mengabulkan permintaan tersebut. Alasan-alasan ini dapat dikemukakan pada bagian awal, sebelum permintaan langsung disampaikan, dapat pula dikemukakan pada bagian akhir, sesudah permintaan langsung disampaikan.

Penempatan argumentasi pada bagian awal dimaksudkan untuk menyiapkan kondisi tertentu agar permintaan tersebut layak disampaikan. Dalam hal ini tampak bahwa anak merasa perlu menyampaikan sesuatu terlebih dahulu sebelum menyampaikan permintaannya kepada mitra tutur untuk mengkondisikan pemintaan tersebut agar mitra tuturnya dapat memaklui permintaan yang disampaikannya. Perlunya penyiapan kondisi tertentu sebelum mengajukan permintaan ini dipengaruhi oleh adanya kendala tertentu yang mengganggu kelayakan pengajuan permintaan. Oleh karena itu, anak memandang perlu mengemukakan pernyataan-pernyataan tertentu untuk menetralisir atau mengkondisikan terlebih dahulu situasi dan kondisi yang dihadapinya sebelum menyampaikan permintaannya. Pernyataan "Nanti kalau uangnya sudah banyak" pada contoh data wacana (9), misalnya, digunakan oleh anak untuk menyiapkan kondisi kelayakan pengajuan permintaan terhadap mobil berkendali jarak jauh yang harganya sangat mahal. Dengan pernyataan tersebut anak berharap kondisi yang tidak tepat saat mengajukan permintaannya, bahwa uang bapak sedang tidak cukup banyak untuk mengabulkan permintaan anak, dapat dinetralisir oleh anak sebelum mengajukan permintaannya. Sementara itu, penempatan alasan pada bagian akhir kalimat permintaan dimaksudkan untuk memberikan alasan lebih 
lanjut terhadap permintaan yang telah diajukan. Munculnya argumentasi setelah permintaan diajukan ini dapat disebabkan pertimbangan anak akan perlunya argumentasi tersebut untuk mendukung permintaannya. Pernyataan "berat banget sih" yang mengikuti permintaan "pak, tolong bawain tasku" pada contoh data wacana (10) digunakan oleh anak untuk meyakinkan dan mendukung permintaan yang telah diajukannya.

Studi sebelumnya tentang bagaimana pengunaan tindak tutur ekspresif permintaan maaf anak usia 5 tahun. Namun pada studi ini berfokus pada stategi meminta anak usia 6 tahun. Pada studi in terdapat dua hal pokok dalam permintaan langsung dengan argumentasi, yaitu bagian yang memuat permintaan langsung dan bagian yang memuat argumentasi. Bagian permintaan langsung digunakan untuk menyampaikan informasi sejelas-jelasnya, sedangkan bagian argumentasi digunakan untuk menjaga hubungan baik dengan mitra tutur agar komunikasi berjalan dengan baik dan lancar.

\section{Pembahasan}

\section{Strategi meminta Anak Usia Dini usia 6 tahun}

Hasil penelitian menunjukan bahwa dalam mengajukan permintaannya, anak usia dini (usia 6 tahun) sering melakukannya dengan cara menyebut langsung sesuatu yang diminta tanpa basa basi. Hal tersebut dikarenakan kondisi yang melatarbelakangi permintaan anak dan memungkinkan bagi anak untuk merasa tetap dapat mempertahankan keberlangsungan dan kesantunan komunikasi meskipun diajukan dengan menggunakan bentuk permintaan langsung pada sasaran, kondisi permintaan anak ini sejalan dengan yang dikatakan oleh Revita et al. (2012). Permintaan anak usia dini secara garis besar terdiri dari dua pola. yaitu:

\section{Permintaan Anak Usia Dini (usia 6 tahun) Langsung ke Sasaran}

Permintaan langsung pada sasaran digunakan oleh anak untuk mengajukan permintaan dalam beberapa kondisi, yaitu:

Pertama, permintaan langsung pada sasaran digunakan oleh anak usia dini (usia 6 tahun) jika 'sesuatu' yang diminta merupakan kebiasaan yang selalu terjadi secara berulangulang. Dengan kebiasaan terjadi secara berulang dan tidak ada penolakan terhadap permintaan tersebut. Anak merasa yang diminta yakin didapatkan. Pengajuan permintaan berfungsi sebagai pemberitahuan kepada mitra tutur. Sehingga membuat anak tidak ada beban psikologis dalam mengajukan permintaan. Permintaan yang diajukan anak tidak mengganggu hubungan baik dan komunikasi dengan mitra tuturnya.

Kedua, permintaan langsung pada sasaran digunakan oleh anak usia dini dalam mengajukan permintaannya jika yang diminta merupakan hak yang sudah layak diterima dari mitra tuturnya.

Ketiga, permintaan langsung pada sasaran digunakan oleh anak usia dini (usia 6 tahun) jika kedekatan hubungan antara anak dengan mitra tutur yang dihadapi termasuk dalam kategori sangat dekat dan status sosial dari segi usia anak lebih tua atau sederajat dengan mitra tuturnya. Anak tidak memerlukan basa basi namun tetap menjaga hubungan baik dan kesopansantunan dengan mitra tuturnya. Anak tidak melanggar prinsip sopan santun meskipun menggunakan bentuk permintaan langsung pada sasaran, begitu juga mitra tuturnya merasa tidak dilanggar hak dan harga dirinya. Hal ini sejalan dengan pandangan bahwa tingkat kedekatan hubungan atau keakraban antara penutur dan mitra tutur berbanding terbalik dengan tingkat kesantunan yang diperlukan dalam berkomunikasi Lacey et al. (2022) ; Rusbiyantoro (2014).

Keempat, permintaan langsung digunakan oleh anak untuk mengajukan permintaan jika ada dukungan moral dari seseorang yakni memilki kedudukan dan memiliki pengaruh terhadap mitra tutur. Wujud dukungan dapat berupa persetujuan yang diminta oleh anak maupun janji yang disampaikan seseorang yang dapat diandalkan anak. Anak memiliki rasa 
percaya diri mengajukan permintaannya menggunakan bentuk permintaan langsung. Anak tidak perlu menggunakan bentuk permintaan secara tidak langsung untuk menjaga hubungan baik dengan mitra tutur karena telah mendapatkan dukungan moral dari seseorang.

\section{Permintaan dengan Mengunakan Alasan/Argumentasi}

Permintaan langsung dengan alasan dan argumentasi anak kepada mitra tuturnya dilakukan untuk meyakinkan serta mempengaruhi mitra tutur agar memahami dan memaklumi permintaannya untuk dikabulkan. Anak merasa perlu menyampaikan sesuatu terlebih dahulu sebelum menyampaikan permintaannya kepada mitra tutur untuk mengkondisikan pemintaan tersebut agar mitra tuturnya dapat memaklumi permintaan. Munculnya argumentasi setelah permintaan diajukan ini dapat disebabkan pertimbangan anak akan perlunya argumentasi tersebut untuk mendukung permintaannya. Bagian permintaan langsung digunakan untuk menyampaikan informasi sejelas-jelasnya, sedangkan bagian argumentasi digunakan untuk menjaga hubungan baik dengan mitra tutur agar komunikasi berjalan dengan baik.

\section{SIMPULAN}

Berdasarkan temuan dapat di sintesiskan bahwa strategi anak usia 6 tahun dalam mengajukan permintaan, yaitu; permintaan dilakukan bila yang diminta merupakan kebiasaan dilakukan berulang. Permintaan menggunakan kata imperative seperti kata minta, belikan, ambilkan. Cara anak mengajukan permintaan langsung dapat diklasifikasi atas dua cara yaitu langsung ke target sasaran dan permintaan dengan alasan/ argumentasi. Sesuatu yang diminta merupakan hak yang sudah seharusnya. Cara anak melakukan permintaan bila ada dunkungan moral, anak lebih berani argumentasi. Oleh karena itu, anak mengemukakan yang dapat menciptakan kondisi tertentu sehinga permintaan layak disampaikan dan dimaklumi mitra tuturnya.

\section{UCAPAN TERIMAKASIH}

Terima kasih kami ucapkan kepada teman teman dosen senior, pimpinan baik Fakultas maupun Universitas, Prodi PIAUD yang sudah memberi masukan serta mendukung dalam mmenyelesaikan penelitian anak usia dini yang mana anak khususnya usia 6 tahun mempunyai strategi dalam meminta sehinga kita harapkan pihak guru maupun orang tua dapat mengetahui anak perlu dipahami keinginannya dengan cara cara yang baik dan bersahaja.

\section{DAFTAR PUSTAKA}

Anggraini, N. (2021). Peranan Orang Tua Dalam Perkembangan Bahasa Anak Usia Dini. Metafora: Jurnal Pembelajaran Bahasa Dan Sastra, 7(1), 43. https:// doi.org/10.30595/mtf.v7i1.9741

Christiana, W. (2018). Lagu Anak Sebagai Repertoar Alternatif Pembelajaran Gitar Klasik Pada Anak Usia Sekolah Dasar. Jurnal Pendidikan Dan Kajian Seni, 3(2), 195-215. https://doi.org/10.30870/jpks.v3i2.4581

Fauziah, F., \& Rahman, T. (2021). Meningkatkan Perkembangan Bahasa Anak Usia Dini Melalui Metode Bercerita. Jurnal Kajian Anak (J-Sanak), 2(02), 108-114. https://doi.org/10.24127/j-sanak.v2i02.870

Findy Novita, A. F. (2020). Pengaruh Lingkungan Keluarga Terhadap Tindak Tutur Anak. Prosiding Samasta, $1-6$. https://jurnal.umj.ac.id/index.php/SAMASTA/article/viewFile/677 - 684/6652

$\begin{array}{ccccc}\text { Gratzer, W. (2008). The golden age. Biochemist, } & 30(6), & \text { 8-10. } \\ \text { https://doi.org/10.1042/BIO03006008 }\end{array}$
https:// doi.org/10.1042/BIO03006008 
DOI: 10.31004/obsesi.v6i4.2245

Hovy, D., \& Yang, D. (2021). The Importance of Modeling Social Factors of Language: Theory and Practice. 588-602. https://doi.org/10.18653/v1/2021.naacl-main.49

Jannah, M. (2015). Tugas-Tugas Perkembangan Pada Usia Kanak-Kanak. Gender Equality: International Journal of Child and Gender Studies, 1(2), 89-91.

Lacey, K. K., Parnell, R., Drummond-Lewis, S. R., Wood, M., \& Sears, K. P. (2022). Physical intimate partner violence, childhood physical abuse and mental health of u.S. caribbean women: The interrelationship of social, contextual, and migratory influences. International Journal of Environmental Research and Public Health, 19(1). https://doi.org/10.3390/ijerph19010150

Lee, L., Williams, A., Lao, C., Lagunas, N., \& Langner, C. A. (2021). The role of home language in children's friendship choice and peer acceptance. Journal of Applied Developmental $\begin{array}{llll}\text { Psychology, } & 76 & \text { (September } & 2020),\end{array}$ https://doi.org/10.1016/j.appdev.2021.101323

Legare, C. H., Mills, C. M., Souza, A. L., Plummer, L. E., \& Yasskin, R. (2013). The use of questions as problem-solving strategies during early childhood. Journal of $\begin{array}{llll}\text { Experimental Child } & \text { 63-76. }\end{array}$ https://doi.org/10.1016/i.jecp.2012.07.002

Loukatari, P., Matsouka, O., Papadimitriou, K., Nani, S., \& Grammatikopoulos, V. (2019). Kindergarten Children. International Journal of Instruction, 12(3), 237-252. https://doi.org/10.29333/iji.2019.12315a

Musyikawati, D. A. (2015). Alih Kode dan Campur Kode Antara Penjual dan Pembeli ( Analisis Pembelajaran Berbahasa Melalui Studi Sosiolinguitik). Dimensi Pendidikan Dan Pembeljaran, 3(2), 23-32. http://journal.umpo.ac.id/index.php/dimensi/article/viewFile/154/141

Pranita, U., Kurniah, N., \& Suprapti, A. (2018). Supervisi Klinis Kepala Sekolah Pendidikan Anak Usia Dini Islam Terpadu Auladuna Kota Bengkulu. Jurnal Ilmiah Potensia, 3(1), 54-65. https://doi.org/10.33369/jip.3.1.54-65

Raco, J. (2018). Metode penelitian kualitatif: jenis, karakteristik dan keunggulannya. https://doi.org/10.31219/osf.io/mfzuj

Ramda, A. H., Prahmana, R. C. I., Mulu, H., \& Gunur, B. (2018). Kemampuan Konservasi Panjang Pada Siswa Usia 6-7. Jurnal Gantang, 3(2), 109-116. https://doi.org/10.31629/jg.v3i2.480

Revita, I., Wijana, I. D. P., \& Poedjosoedarmo, S. (2012). Permintaan Dalam Bahasa Minangkabau. Humaniora, 19(2), 195-206.

Rusbiyantoro, W. (2014). Kesantunan Melalui Pemilihan Kata sapaan dalam Bahasa Melayu Kutai : Suatu Kajian Sosiopragmatik. Seminar Nasional Prasasti (Pragmatik: Sastra Dan Linguistik), 275-283.

Sastra, S., Nim, N., Arafah, R. H., Studi, P., Jurusan, S. I., \& Indonesia, S. (2016). Tuturan direktif dalam wacana. http://lib.unnes.ac.id/28717/1/2111411036.pdf

Setyowati, R. (2020). Strategi 'Meminta Maaf' Anak Usia Pra-Sekolah di Lembaga Pendidikan daQukids Semarang. Diglosia: Jurnal Kajian Bahasa, Sastra, Dan Pengajarannya, 3(1), 87-101. https:// doi.org/10.30872/diglosia.v3i1.56

Usman, M. (2015). Perkembangan Bahasa dalam Bermain dan Permainan: Untuk Pendidikan Anak. Google Buku. In deepublish, Yogyakarta (p. 129). Deepublish.

Wahyuni, A. (2018). The Power of Verbal and Nonverbal Communication in Learning. January. https://doi.org/10.2991/icigr-17.2018.19

Wolf, M. M. (1978). Social validity: the case for subjective measurement or how applied behavior analysis is finding its heart1. Journal of Applied Behavior Analysis, 11(2), 203214. https:// doi.org/10.1901/jaba.1978.11-203

Yoder, P. J., \& Warren, S. F. (2002). Teaching and Parent Responsivity. Hearing Research, $\mathrm{V}$ (December). 